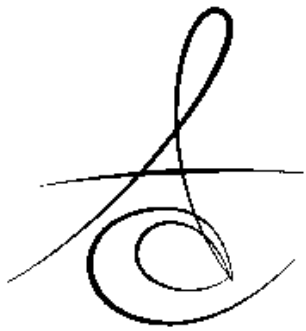

\title{
EFFECT OF CURING UNITS AND ADHESION STRATEGIES ON MICROLEAKAGE OF BULK-FILL COMPOSITES: AN IN VITRO STUDY ${ }^{\ddagger}$
}

\section{IŞIK CIHAZLARI VE ADHEZYON STARTEJILERININ KÜTLESEL IŞIKLANABILEN KOMPOZITLERIN MIKROSIZINTILARI ÜZERINE ETKILERI: IN-VITRO ÇALIŞMA}

\author{
Doç. Dr. Betul MEMİş ÖZGüL* \\ Doç. Dr. R. Ebru TİRALí *
}

Uzm. Dt. G. Burcu BOSTANCI*

Prof. Dr. Sevi Burcak ÇEHRELI**

Makale Kodu/Article code: 3647

Makale Gönderilme tarihi: 25.04.2018

Kabul Tarihi; 27.07.2018

\section{ABSTRACT}

Aim: This study was performed to investigate the effects of different light-curing units on microleakage of bulk-fill composites applied using different adhesion strategies (self-etch or selective etch).

Material and Methods: Twenty-six extracted third molar teeth were randomly divided into 2 groups $(n=13)$ according to the light-curing units used: either a quartz tungsten halogen lamp or light-emitting diode lamp. Two standardized occlusal cavities $(2 \times 3 \times 3 \mathrm{~mm})$ were prepared on each tooth to create subgroups (self-etch or selective etch). Cavities in the elective etch subgroup were etched prior to restoration procedures using $37 \%$ orthophosphoric acid. All cavities were then restored with a nano-filler bulk-fill composite resin using Universal Bond (All-Bond Universal; Bisco, Schaumburg, IL, USA) as an adhesive. The light activations were performed according to the light-curing units. Teeth were thermocycled 2500 times at $5^{\circ} \mathrm{C}-55^{\circ} \mathrm{C}$, then immersed in $0.5 \%$ basic fuchsin solution for 24 hours. Microleakage was quantitatively assessed using the dye-penetration method along with quantitative computer-aided image measurement. Data analysis was performed using the Mann-Whitney $U$ test.

Results: The selective etch group had significantly lower microleakage measurements than the Universal Bond group $(p<0.05)$ in both the quartz tungsten halogen lamp and light-emitting diode lamp curing groups. However, there was no significant difference between the self etch and selective etch subgroups according to the light-curing units used $(p>0.05)$.

Conclusions: The selective etch method provides better adhesion when bulk-fill composites are used regardless of the light-curing units being used.

Keywords: Bulk-fill composites, LED, self-etch technique, selective etch technique, QTH.

\section{ÖZ}

Amaç: Bu çalışma, farklı ışık-polimerizasyon ünitelerinin farklı adhezyon stratejileri (self-etch veya selektif etch) kullanılarak uygulanan kütlesel ışıklanabilen kompozitlerin mikrosızıntısı üzerindeki etkilerini araştırmak amacıyla yapılmıştır.

Gereç ve Yöntem: 26 adet çekilmiş üçüncü molar diş, kullanılan ışık-polimerizasyon ünitelerine göre quartz tungsten halojen (QTH) veya ışık yayan diyot (LED) olmak üzere 2 gruba $(n=13)$ ayrıldı. Alt grupları oluşturmak amacıyla (self-etch(SE) veya selektif etch (SLE)) her diş üzerinde iki standart okluzal kavite $(2 \times 3 \times 3 \mathrm{~mm})$ hazırlandı. SLE alt grubundaki kaviteler, \%37'lik ortofosforik asit kullanılarak restorasyon prosedürlerinden önce hazırlandı. Tüm kaviteler daha sonra Universal Bond (AllBond Universal; Bisco, Schaumburg, IL, ABD) bağlayıcI ajan kullanılarak bir nano dolduruculu kütlesel ışıklanabilen kompozit rezinle restore edildi. Işık aktivasyonları ait oldukları grubun ışık-polimerizasyon ünitelerine göre yapıldı. Dişler, $5^{\circ} \mathrm{C}-55^{\circ} \mathrm{C}$ de $2500 \mathrm{kez}$ termal döngüye tabi tutuldu daha sonra 24 saat boyunca $\% 0.5$ bazik fuksin çözeltisinde bekletildi. Mikrosızıntı, boya-penetrasyon yöntemi kullanılarak, bilgisayar destekli görüntü ölçümü ile kantitatif olarak değerlendirildi. Veri analizi MannWhitney U testi kullanılarak yapıldı.

Bulgular: Selektif etch (SLE) grubu için hem quartz tungsten halojen hem de ışık yayan diyot gruplarında Universal Bond grubuna göre $(p<0.05)$ anlamlı derecede düşük mikro-sızıntı ölçümleri bulgulandı. Bununla birlikte kullanılan ışık-polimerizasyon ünitesine göre self-etch ve selektif etch alt grupları arasında anlamlı fark görülmedi (p> 0.05).

Sonuç: SLE yöntemi, kullanılan ışık cihazından bağımsız olarak kütlesel olarak ışıklanabilen kompozitler kullanıldığında daha iyi bir adezyon sağlamıştır.

Anahtar Kelimeler: Bulk-fill kompozitler, LED, self- etch tekniği, selektif etch tekniği, QTH

\footnotetext{
* Baskent University Faculty of Dentistry, Department of Pediatric Dentistry, Ankara.

** Lefke European University Faculty of Dentistry, Department of Pedodontics, Lefke, Mersin, KKTC.

${ }^{\ddagger}$ This paper was presented as a poster at the 13th European Association of Paediatric Dentistry

Congress, 2-5 June 2016, Belgrade, Serbia
} 


\section{INTRODUCTION}

The use of direct resin-based composite (RBC) restorations has increased with the demand for minimally invasive treatments and tooth-colored restorations. However, the placement of a direct RBC restoration requires sensitive operative techniques to achieve success. Every step of the technique, including the bonding procedures, placement of the composite into the cavity, and curing, present a series of challenges that the clinician must overcome to ensure high-quality, long-lasting restorations ${ }^{1}$.

Direct composite resin restorations are generally placed in increments of $2 \mathrm{~mm}^{2}$. However, there are some issues with this method. One issue is that it is time-consuming and associated with the development of voids and porosity, especially in deep posterior cavities ${ }^{3,}{ }^{4}$. Bulk-fill composites were therefore introduced to overcome this problem of conventional RBCs. Bulk-fill composites have low volumetric polymerization shrinkage hence can be used in thicknesses of up to $4 \mathrm{~mm}$ in one increment , resulting in low polymerization shrinkage stress ${ }^{5,6}$.

Choosing an adequate adhesive system is one of the most important factors in restoration success. However, this is a fairly difficult task because many alternatives are available on the market ${ }^{1}$. Two main adhesive systems are currently in use: the etchand-rinse method and the less time-consuming selfetch (SE) method ${ }^{7}$. Both methods are considered to provide adequate dentin bonding; however, the etchand-rinse method is more effective for enamel bonding $^{8,9}$. A new-generation adhesive system was recently introduced as a "universal" or "multi-mode" adhesive $^{10,11}$. This system is basically a one-step SE adhesive that can also be used with phosphoric acid (selective etch [SLE]). This versatile bonding system enables the practitioner to choose the best-suited method for each single cavity.

Another important aspect of direct composite restorations is the light-curing unit (LCU) that is used. The most commonly used LCUs are quartz tungsten halogen (QTH) lamps, which are still considered the gold standard for photopolymerization ${ }^{12}$. However, QTH LCUs have limitations, such as the need to replace the fans and optical filters, short lifetime, and relatively long exposure time ${ }^{13}$. Light-emitting diode (LED) LCUs have been developed to overcome these problems.
The effects of different LCUs and polymerization strategies on bulk-fill composites have not been thoroughly investigated, especially with respect to microleakage. Microleakage does not influence the development of secondary caries in the short term, but the loss of marginal integrity due to microleakage leads to interfacial gap formation and subsequent biofilm formation around sealant margins, which may in turn initiate the development of caries lesions ${ }^{14}$. In the present study, the effect of different adhesive and polymerization strategies on the microleakage of newly developed bulk-fill RBCs was investigated. The null hypothesis was that the choice of LCU and adhesion protocol would not affect the level of microleakage around bulk-fill restorations.

\section{MATERIALS AND METHODS}

This study was approved by the Baskent University Institutional Review Board (project No. DDA16/03) and supported by the Baskent University Research Fund.

Twenty-six extracted third molar teeth free from caries, cracks, and hypoplastic defects were used in the study. The external debris was removed from the teeth with a hand-scaler and cleaned using pumice before cavity preparation. The teeth were stored in distilled water for a maximum of 1 month, and the water was changed weekly to prevent bacterial growth. Cavities were prepared using diamond burs (Meisinger, Neuss, Germany) under a water-cooled high-speed handpiece (Silent Power 4L; Castellini, Imola, Italy). Two standardized occlusal cavities $(2 \times 3 \times 3 \mathrm{~mm})$ were prepared on each tooth. The teeth were then randomly divided into two groups according to the curing protocol used $(n=13)$. The outputs of the curing lights were $600 \mathrm{~mW} / \mathrm{cm}^{2}$ (Hilux) and 1200 $\mathrm{mW} / \mathrm{cm}^{2}$ (Elipar S10). For each tooth, one of the cavities was randomly chosen for the SE or SLE method.

\section{Group A: QTH (Hilux; Benlioglu Dental, Ankara, Turkey)}

Following the cavity preparations, the teeth were washed thoroughly with water spray, and excess water was gently removed with air spray. Each cavity was restored according to the adhesion protocol.

\section{SE Group (Cavity 1)}

Two separate coats of Universal Bond (AllBond Universal; Bisco, Schaumburg, IL, USA) were

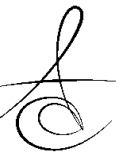


applied by scrubbing the preparation with a microbrush for 10 to 15 seconds per coat. Next, the excess solvent was removed by thoroughly air-drying with an air syringe for at least 10 seconds and then light-cured for 20 seconds with a QTH LCU. The cavities were restored with a nano-filled bulk-fill composite resin (Filtek Bulk Fill; 3M ESPE, St. Paul, $M N$, USA) in one increment, then light-cured for 40 seconds with the QTH LCU.

\section{SLE Group (Cavity 2)}

As the first step of the restoration, cut and uncut enamel were etched for 15 seconds using $37 \%$ orthophosphoric acid. The rest of the procedures were performed as described for the SE Group.

\section{Group B: LED lamp (Elipar S10; 3M ESPE)}

Following the cavity preparations, the teeth were washed thoroughly with water spray, and excess water was gently removed with air spray. Each cavity was restored according to the adhesion protocol.

\section{SE Group (Cavity 1)}

Two separate coats of Universal Bond (AllBond Universal; Bisco) were applied by scrubbing the preparation with a microbrush for 10 to 15 seconds per coat. Next, the excess solvent was removed by thoroughly air-drying with an air syringe for at least 10 seconds, then light-cured for 10 seconds with an LED LCU. The cavities were restored with a nano-filled bulk-fill composite resin (Filtek Bulk Fill; 3M ESPE) in one increment, then light-cured for 20 seconds with the LED LCU.

\section{SLE Group (Cavity 2)}

As the first step of the restoration, cut and uncut enamel were etched for 15 seconds using $37 \%$ orthophosphoric acid; the rest of the procedures were performed as described for the SE Group. Finishing and polishing were performed using a Sof-Lex Finishing and Polishing System (3M ESPE).

\section{Microleakage evaluation}

The conventional dye-penetration method along with quantitative measurement was used to test the amount of microleakage. The teeth were subjected to thermocycling ( 2500 times at $5^{\circ} \mathrm{C}-55^{\circ} \mathrm{C}$ ) with a 15 -second dwell time and 10 -second transfer time following the finishing of restorations. The tooth surfaces were coated with two layers of nail varnish (Maybelline, New York, NY, USA) up to $1 \mathrm{~mm}$ from the restoration margins after the thermocycling procedures. The samples were then immersed in $0.5 \%$ basic fuchsin solution (Wako Pure Chemical Industry, Osaka, Japan) for 24 hours. Thereafter, the samples were thoroughly rinsed under tap water until no dye was observed, air-dried, and embedded in epoxy resin (Struers, Copenhagen, Denmark). A parallel longitudinal section was made through the occlusal surfaces in the mesio-distal direction using a water-cooled lowspeed diamond saw (Isomet; Buehler, Lake Bluff, IL, USA). Each section was digitally photographed using an X20 (1280 $\times 1024$ resolution) under a stereomicroscope (Olympus, Tokyo, Japan). The images were transferred to a Macintosh computer in TIFF format. Open-source image analysis software (Image J, V.1.42; National Institutes of Health, Bethesda, MD, USA) was used to measure the extent of mesial and distal dye penetration along the enamel-restoration interface in millimeters. The microleakage value for each section was calculated by dividing the sum of the mesial and distal dye penetration values by the sum of the lengths of the mesial and distal enamel-restoration interfaces as described by Cehreli et al. ${ }^{15}$. The measurements were made by a single calibrated operator (B.C.) blinded to the test groups. The microleakage value for each specimen and for each tooth and subgroup were calculated as the mean \pm standard deviation.

\section{Statistical Analysis}

Data analysis was performed using SPSS for Windows, version 11.5 (SPSS Inc., Chicago, IL, USA). Normality of the continuous variable distribution was determined using the Shapiro-Wilk test. The KruskalWallis test was used to evaluate homogeneity. The statistical significance of median values between two groups was evaluated using the Mann-Whitney U test, with $p<0.05$ considered statistically significant.

\section{RESULTS}

The quantitative data showed that the SLE group had significantly lower microleakage measurements than the SE group $(p<0.05)$ in both the QTH and LED LCU groups. However, there was no significant difference between the SLE and SE groups according to the LCU used ( $p>0.05)$ (Table 1). The lowest microleakage scores were observed in the SLE+LED group, and the highest microleakage scores were observed in the QTH+SE group (Figure 1).

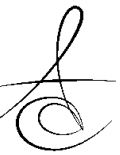


Table 1. Microleakage scores

\begin{tabular}{|l|l|l|}
\hline \multirow{2}{*}{ LCU units } & \multicolumn{2}{|l|}{ Adhesion strategies } \\
\cline { 2 - 3 } & SE & SLE \\
\hline QTH & $0,1558 \pm 0,08058^{\mathrm{a}, \mathrm{A}}$ & $0,0841 \pm 0,05905^{\mathrm{a}, \mathrm{B}}$ \\
\hline LED & $0,1412 \pm 0,0734^{\mathrm{a}, \mathrm{A}}$ & $0,0730 \pm 0,0447^{\mathrm{a}, \mathrm{B}}$ \\
\hline
\end{tabular}

Values followed by the same small letter in the same column indicates microleakage scores that are not significantly different at a level of $p>0.05$, and values followed by the different capital letters in the same row indicate microleakage scores that are significantly different at a level of $p>0.05$.

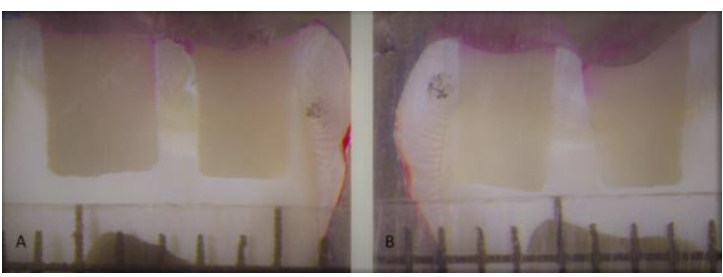

Figure 1. A. Sample QTH LCU unit. B. Sample LED LCU unit. The sides with the black spot show the cavities that underwent the SLE procedure.

\section{DISCUSSION}

This study investigated the effects of different LCU and adhesion strategies on microleakage of bulk-fill composites. The results of the study showed no difference between the QTH and LED LCUs, and the SLE adhesion strategy performed better than the SE strategy; thus, our hypothesis was partly rejected.

Faria-e-Silva et al. ${ }^{16}$ investigated the effect of LCUs and the SE and total-etch techniques on the degree of conversion of bonding agents. Their results indicate that the impact of QTH and LED lights on the degree of conversion of bonding agents were depending on material and that the SE technique with the QTH performed more effectively. In the present study, we found no differences among the LCUs according to the bonding strategy used, but the products used differed between the present and above-mentioned studies; therefore, it may be misleading to further compare these studies.

Several studies have investigated the different polymerization properties of bulk-fill composites with LED LCUs ${ }^{17,18}$. To the best of our knowledge, however, this is the first study to compare the effects of QTH and LED LCUs on the microleakage values of bulk-fill composite resins. Some studies are investigating the effect of LCU units on microleakage of different resin-based restorations.

Cehreli et al. ${ }^{19}$ investigated the effect of LEDs and QTH LCUs on microleakage of ormocer-based fissure sealants and found no difference among the LCU units used. Another study investigated the effects of QTH and LED LCUs on microleakage of resin-based fissure sealants and concluded that the microleakage values for the LED LCU was lower than that for the QTH LCU ${ }^{20}$.

Zakavi et al. ${ }^{21}$ evaluated microleakage class II composite resin restorations cured with LED or QTH LCUs in vitro and showed that the LED LCU with different curing modes was more effective than the QTH LCU for reducing microleakage. Soares et al. ${ }^{22}$ investigated microleakage in Class $V$ cavities restored with microhybrid composite resin with LED and QTH LCUs. The authors showed that among the cavities not submitted to thermal and mechanical load cycling, the QTH LCU showed lower microleakage than did the LED LCU. For those subjected to thermal and mechanical load cycling, the QTH LCU showed lower microleakage than the LED LCU, but a statistically significant difference was only observed in one type of microhybrid composite used in the study.

Studies investigating the effects of QTH and LED LCUs on microleakage of resin-based materials have shown different results. However, the present study is the first to investigate these effects on bulk-fill composites and demonstrated no significant difference between the two LCU units used in this study.

Takamizawa et al. ${ }^{23}$ investigated whether the use of total-etch or SE for different brands of universal bonds would have an impact on the bond strength and fatigue strength of the adhesives to dentin. Their results showed that the bond strength of universal adhesives to dentin depends on the adhesive material being used. However, All-Bond Universal, which is the same brand used in the present study, showed greater bond strength when used in the total-etch mode. These findings might be considered to be in accordance with our results. In the present study, however, we chose the SLE method and thus only etched the enamel. This was because previous reports have suggested that when normal SE adhesives are used and dentin is pretreated with phosphoric acid, the resin components of the SE adhesive might not penetrate the exposed collagen network as expected; this could result in a lower bond strength in dentin ${ }^{24}$, ${ }^{25}$. Even if the bond strength is not reduced, Hanabusa

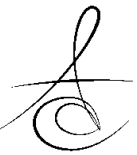


Atatürk Üniv. Diş Hek. Fak. Derg.

J Dent Fac Atatürk Uni

Cilt:29, Sayı:1, Yıl: 2019, Sayfa, 74-79

et al. $^{26}$ showed that the adhesive interface appeared more vulnerable ultrastructurally to biodegradation when the dentin is etched prior.

Loguercio et al. $^{27}$ investigated the performance of universal bonding systems using the SE, SLE, and TE methods with conventional RBC restorations for 36 months. Although their results showed no significant differences among the bonding strategies, the SE group showed the least effectiveness.

An in vivo study by Loguercio et al. ${ }^{28}$ used different brands of universal bonds with different adhesion strategies (active SE, passive SE, and SLE). Their results revealed that when the universal bond is applied in active mode (meaning that while applying the adhesive, manual pressure is applied and a microbrush is scrubbed on the cavity), it performs better than when the adhesive is simply applied and then left alone (passive SE). The authors showed that active SE application of universal bond might be a good alternative to SLE in specific clinical situations. In the present study, we applied the universal bond by scrubbing the preparation with a microbrush, which is defined as active SE according to Loguercio et al. ${ }^{28}$.

McHugh et al. ${ }^{29}$ investigated the microleakage of conventional and bulkfill RBC restorations either unbonded or bonded with universal bonding system. They concluded that not all conventional and bulkfill RBC showed similar microlekage scores used for same standardized cavities with standardized protocols, they suggest that the LCU may cause these differences and should be examined. However in the previous study we found no such differences between LCUs used in the study but we only tested one bulkfill composite.

The results of the present study showed that the adhesion strategy plays a more important role than does the photopolymerization protocol. However, it should be kept in mind that an important limitation of this study is the in vitro tests performed while interpreting the clinical outcomes. We used thermocycling followed by immersion in basic fuchsin solution to evaluate the microleakage; however, the clinical environment has more parameters, such as isolation. Thus, an in vivo study will provide further information about the performance of bulk-fill composites applied with different adhesion strategies and photopolymerized with different LCUs.
MEMIŞ ÖZGÜL, BOSTANCI, TİRALI, ÇEHRELI

\section{CONCLUSIONS}

Within the limitations of this study, the results revealed that the adhesion protocol is more effective than the LCU used for elimination of microleakage in bulk-fill composite resins. The SLE adhesion strategy seems to be the most effective approach for bulk-fill composite resin restorations.

Betül Memiş Özgül : ORCID ID:0000-0002-3291-6174

G. Burcu Bostanci: ORCID ID:0000-0003-4918-5504

R.Ebru Tirali: ORCID ID:0000-0001-6487-3984

S. Burçak Çehreli: ORCID ID:0000-0003-2790-3982

\section{REFERENCES}

1-Mackenzie L, Shortall AC, Burke FJ . Direct posterior composites: a practical guide. Dent Update 2009; 36: 71-80.

2- Sakaguchi RL, Douglas WH, Peters MCRB. Curing light performance and polymerization of composite restorative materials. J Dent 1992; 20: 183-8.

3- Opdam NJ, Roeters JJ, Joosten M, Veeke OV. Porosities and voids in Class I restorations placed by six operators using a packable or syringable composite. Dent Mater 2002; 18: 58-63.

4- Roeters JJ, Shortall AC, Opdam NJ. Can a single composite resin serve all purposes? $\mathrm{Br}$ Dent J 2005; 199: 73-9.

5- Bucuta S, Ilie N. Light transmittance and micromechanical properties of bulk fill vs. conventional resin based composites. Clin Oral Investig 2014; 18: 1991-2000.

6- Zorzin J, Maier E, Harre S, Fey T, Belli R, Lohbauer $U$, et al. Bulk-fill resin composites: polymerization properties and extended light curing. Dent Mater 2015; 31: 293-301.

7- Fatma A, Dilek T, Funda Y. Dentine bağlanma ve değerlendirme metodları. Atatürk Üniv Diş Hek Fak Derg. 2011; Suppl: 4 : 49-56.

8- Rotta M, Bresciani P, Moura SK, Grande RH, Hilgert LA, Baratieri LN, et al. Effects of phosphoric acid pretreatment and substitution of bonding resin on bonding effectiveness of self-etching systems to enamel. J Adhes Dent 2007; 9: 537-45.

9- Van Meerbeek B, Yoshihara K, Yoshida Y, Mine A, De Munck J, Van Landuyt KL. State of the art of self-etch adhesives. Dent Mater 2011; 27: 17-28.

10- Wagner A, Wendler M, Petschelt A, Belli R, Lohbauer $U$. Bonding performance of universal adhesives in different etching modes. J Dent 2014; 42: 800-7. 
11- Rosa WL, Piva E, Silva AF. Bond strength of universal adhesives: a systematic review and meta-analysis. J Dent 2015; 43: 765-76.

12- Castillo-Oyagüe R, Milward PJ, Martín-Cerrato A, Lynch CD. Effect of preoperative occlusal matrices on the Vickers microhardness of composite disks polymerized with QTH and LED lamps. J Esthet Restor Dent 2015; 27: 203-12.

13- Rahiotis C, Kakaboura A, Loukidis M, Vougiouklakis G. Curing efficiency of various types of light-curing units. Eur J Oral Sci 2004; 112: 89-94.

14- Cenci MS, Tenuta LM, Pereira-Cenci T, Del Bel Cury AA, ten Cate JM, Cury JA. Effect of microleakage and fluoride on enamel-dentine demineralization around restorations. Caries Res 2008; 42: 369-79.

15- - Cehreli SB, Gungor HC, Karabulut E. Er,Cr:YSGG laser pretreatment of primary teeth for bonded fissure sealant application: a quantitative microleakage study. J Adhes Dent 2006; 8: 381-6.

16- Faria-e-Silva AL, Lima AF, Moraes RR, Piva E, Martins LR. Degree of conversion of etch-and-rinse and self-etch adhesives light-cured using QTH or LED. Oper Dent. 2010; 35: 649-54

17-El-Damanhoury $\mathrm{H}$, Platt J. Polymerization shrinkage stress kinetics and related properties of bulk-fill resin composites. Oper Dent 2014; 39: 374-82.

18- Yap AU, Pandya M, Toh WS. Depth of cure of contemporary bulk-fill resin-based composites. Dent Mater J 2016; 35: 503-10.

19- Cehreli SB, Arikan S, Gulsahi K, Arhun N, Arman A, Sargon $M$. Effect of LED curing on marginal integrity of an ormocer-based sealant. J Dent Child (Chic) 2009; 76: 53-7.

20- Bani M, Tirali RE. Effect of new light curing units on microleakage and microhardness of resin sealants. Dent Mater J 2016; 35: 517-22.

21- Zakavi F, Golpasand Hagh L, Sadeghian S, Freckelton V, Daraeighadikolaei A, Ghanatir $E_{\text {, et }}$ al. Evaluation of microleakage of Class II dental composite resin restorations cured with LED or QTH dental curing light: blind, cluster randomized, in vitro cross sectional study. BMC Res Notes 2014; 7: 416.

22- Soares GP, Ambrosano GM, Lima DA, Marchi GM, Correr-Sobrinho L, Lovadino JR, et al. Effect of light polymerization time, mode, and thermal and mechanical load cycling on microleakage in resin composite restorations. Lasers Med Sci 2014; 29 : 545-50.

23- Takamizawa T, Barkmeier WW, Tsujimoto A, Berry TP, Watanabe $H$, Erickson $R L$, Latta MA, Miyazaki $M$. Influence of different etching modes on bond strength and fatigue strength to dentin using universal adhesive systems. Dent Mater 2016; 32: e9-21.

24- Ikeda $M$, Kurokawa $H$, Sunada $N$, Tamura $Y$, Takimoto $M$, Murayama $R$, et al. Influence of previous acid etching on dentin bond strength of self-etch adhesives. J Oral Sci 2009; 51: 527-534.

25- Van Landuyt KL, Peumans M, De Munck J, Lambrechts $P$, Van Meerbeek $B$. Extension of a one-step self-etch adhesive into a multi-step adhesive. Dent Mater 2006; 22: 533-544.

26- Hanabusa M, Mine A, Kuboki T, Momoi Y, Van Ende A, Van Meerbeek $B$, et al. Bonding effectiveness of a new 'multi-mode' adhesive to enamel and dentine. J Dent 2012; 40: 475-84.

27- Loguercio AD, de Paula EA, Hass V, LuqueMartinez I, Reis A, Perdigão J. A new universal simplified adhesive: 36-month randomized doubleblind clinical trial. J Dent 2015; 43: 1083-92.

28- Loguercio AD, Muñoz MA, Luque-Martinez I, Hass V, Reis A, Perdigão J. Does active application of universal adhesives to enamel in self-etch mode improve their performance? J Dent 2015; 43: 1060-70.

29- McHugh LEJ, Politi I, Al-Fodeh RS, Fleming GJP. Implications of resin-based composite (RBC) restoration on cuspal deflection and microleakage score in molar teeth: Placement protocol and restorative material. Dent Mater. 2017;33: e32935.

\section{Yazışma Adresi}

Betul MEMIS OZGUL

Baskent University Faculty of Dentistry

Department of Pediatric Dentistry

Taskent cad. No 107, Bahcelievler, Ankara, Turkey

Tel: 00905363156948,

Email: dtbetulmemis@hotmail.com 